\title{
Types of pathology and ossicular status in atticoantral disease undergoing mastoidectomy at Bir Hospital
}

\author{
D. Shrestha ${ }^{1}$, P.Thapa ${ }^{2}$, Y. B. Bhandari ${ }^{3}$ \\ ${ }^{1}$ Assistant Professor, ${ }^{2}$ Lecturer, ${ }^{3}$ Sr.consultant, Department of ENT and Head \& Neck Surgery, Bir Hospital, NAMS, Kathmandu, \\ Nepal
}

\begin{abstract}
A prospective study was carried out in the department of ENT and Head and Neck Surgery in Bir Hospital, Kathmandu to know the types of the pathology and the ossicular status in atticoantral disease. This study included 100 cases of CSOM (AA) scheduled for routine mastoidectomy. In this study cholesteotoma was the commonest pathology 61 (61\%) followed by granulation tissue alone in27 (27\%) cases and both cholesteotoma and granulation tissue were found in 12 (12\%) cases. Ossicular damage was more common in CSOM (AA) with granulation tissue in all 27 (100\%), 54(58.06\%) in CSOM(AA) with cholesteotoma and $12(12.9 \%)$ in $\operatorname{CSOM}(\mathrm{AA})$ with both cholesteotoma and granulation tissue. $\mathrm{M}+\mathrm{S}+$ ossicular defect was the commonest ossicular defect 47 (50.53\%) followed by M+S-24(25.80\%), M-S+13(13.97\%)and M-S- 9(9.67\%) cases.
\end{abstract}

Key words: Chronic otitis media, cholesteotoma, granulation tissue, ossicles.

\section{Introduction}

Chronic suppurative otitis media (CSOM) has been defined as typically a persistant disease,insidious in onset, often capable of causing destruction and irreversible sequele, and clinically manifests with deafness and discharge. ${ }^{1}$ Chronic suppurative otitis media atticoantral is also called unsafe or dangerous type. The disease is often associated with a bone eroding process which occur due to the presence of cholesteotoma,granulation tissue or both. The activity if unchecked will eventually lead to invasion and destruction of the inner ear,dural plate, sinus plate, ossicles and facial canal and extend beyond the confines of the temporal bone. ${ }^{2}$ Although, Cholesteotoma incites osseous changes, Correspondence: D. Shrestha E-mail: shrestha_deependra @yahoo.com osseous changes are more frequently found with granulation tissue. ${ }^{3}$

Cholesteotoma or granulation tissue associated with a perforation of pars flaccida of the tympanic membrane produce erosion of the certain portion of the lateral wall of the attic and of the anterior tympanic spine. The lesion extends first laterally to the ossicles. Further growth of the cholesteotoma produces enlargement of the attic,aditus and mastoid antrum and formation of cavity in the mastoid as a result of erosion of the cell walls \&occasionally its further extension may erode the dural plate or sinus plate. ${ }^{4}$ Atticoantral disease is considered to be a dangerous or unsafe form of disease in view of the higher risk of intracranial suppuration. ${ }^{5}$ 
D. Shrestha et al, Types of pathology and ossicular status in atticoantral

CSOM (AA) is one of the common disease in otolaryngologic practice in Nepal. Its importance lies in the fact that it is associated with high morbidity and times even with mortality. Being one of the commonest ear disease, surgery for unsafe ears is one of the commonest operative procedures in ENT Department of Bir Hospital. Good postoperative functional result demands proper preoperative and peroperative assessment of the pathology as well as their correlation with the extent of damage to the ossicular chain. This study was undertaken to assess and correlate types of pathology with the extent of ossicular damage in such patients.

This is a prospective study. This study was conducted in the Department of ENT, Bir Hospital, Kathmandu from Feb 2008 to Feb 2010. The study consisted of 100 patients who were clinically diagnosed as CSOM (AA) type and scheduled for the routine Modified Radical Mastoiedectomy (MRM). History and detail ENT examination including otoscopic examination were done. Otoscopic findings were further confirmed by examination under microscope (EUM) .EUM findings and peroperative findings were noted in the proforma, which were designed for this study.

\section{Materials and methods}

Among 100 patients, cholesteotoma was found in the majority of patients i.e. in $61 \%$, granulation tissue was present only in $27 \%$ patients and both cholesteotoma and granulation tissue were present in $12 \%$ cases.
Among patients with cholesteotoma ossicles were intact in $7(11.47 \%)$ cases and were damaged in $54(88.52 \%)$ cases.However, in patients with granulation tissue ossicular damage were found in all $27(100 \%)$ cases. Similarly in patients with both cholesteotoma and granulation tissue ossicular defect were found in all 12(100\%) cases.

\section{Results}

Ossicular defect $\mathrm{M}+\mathrm{S}+$ was seen in 28 patients with cholesteotoma compared with 14 cases with granulation tissue and 5 cases with both cholesteotoma and granulation tissue.Ossicular defect $\mathrm{M}+\mathrm{S}-$ was seen in 16 patients with cholesteotoma compared with 6 cases with granulation tissue and 2 cases with both cholesteotoma and granulation tissue.Ossicular defect $\mathrm{M}-\mathrm{S}+$ was seen in 4 patients with cholesteotoma compared with 5 cases with granulation tissue and04 cases with both cholesteotoma and granulation tissue.Ossicular defect M-S- was seen in 06 patients with cholesteotoma compared with 2 cases with granulation tissue and 1 case with both cholesteotoma and granulation tissue.

Table I. Types of pathology and association with overall ossicular status

\begin{tabular}{lccc}
\hline $\begin{array}{c}\text { Status of } \\
\text { ossicles }\end{array}$ & Cholesteotoma & $\begin{array}{r}\text { Granulation } \\
\text { tissue }\end{array}$ & $\begin{array}{r}\text { Both gr \& } \\
\text { cholesteotoma }\end{array}$ \\
\hline Intact & 07 & 0 & 0 \\
Damaged & 54 & 27 & 12 \\
Total & 61 & 27 & 12 \\
\hline
\end{tabular}


Journal of College of Medical Sciences-Nepal,2010, Vol-6,No-4

Table.II. Association of pathology with ossicular damage according to Austin's classification.

\begin{tabular}{lcccc}
\hline \multicolumn{5}{c}{ Pathology } \\
Ossicular & Cholesteotoma & Gr. & Both gr \& & Total \\
defect & & Tissue & cholesteotoma \\
\hline M+S+ & 28 & 14 & 05 & 47 \\
M+S- & 16 & 06 & 02 & 24 \\
M-S+ & 04 & 05 & 04 & 13 \\
M-S- & 06 & 02 & 01 & 09 \\
Total & 54 & 27 & 12 & 93 \\
\hline
\end{tabular}

\section{Discussion}

Chronic Otitis Media (Atticoantral) is the commonest ear disease in the OPD of ENT and Head and Neck Surgery of Bir Hospital. In this study the most commonly affected age group was 11-20 years with 24\% patients. This finding was consistent with that of Udaipurwala et al. ${ }^{6}$ and Banskota et al. ${ }^{7}$ In their study they had 59(40.70\%) and $115(48.73 \%)$ patients respectively in this age group. The reason behind this may be that this is socially the most active and health conscious age group.

This study consist of 59 male and 41 female patients, the ratio being $3: 2$ with male preponderance. Previous study done by Banskota et al. ${ }^{7}$ also had similar sex ratio with $165(69.92 \%)$ male patients However, another study done by sachadeva et al. ${ }^{8}$ showed male predominance in the ratio of 2:1.Male predominance in this study could have partly been due to derivation of study population mainly from male dominated section of society.

In this study cholesteotoma was found in 61 cases and granulation tissue was found in 27 cases. In a similar study done by D.K.Banskota et al. ${ }^{7}$ cholesteotoma was found in 206(87.28\%) cases and granulation tissue in $30(12.71 \%)$ cases. I.H. Udaipurwala et al. ${ }^{6}$ reported granulation tissue in 91(62.75) and cholesteotoma in 30(23.07\%) cases. Thapa et al. ${ }^{9}$ found similar result with cholesteotoma in $91(84.26 \%)$ cases and granulation tissue in $17(15.74 \%)$ cases. However in a similar study done by Meyerhoff et al. ${ }^{10}$ granulation tissue was found much more frequently than cholesteotoma.

Ossicular damage is very common pathology associated with chronic suppuration of middle ear. In addition to involvement of tympanic membrane, ossicular damage is the cause of conductive hearing loss in CSOM. In this study only in 7 cases ossicles were intact and they were damaged in 93 cases. Thapa et al found similar result with ossicular defect in 96(88.89\%) cases of CSOM (AA). In a study done by W.Y. Chao and C.C. Wu. ${ }^{11}$ erosion of ossicles was seen in 34(35.42\%) cases and intact ossicles in 13(13.54\%)cases. I.H. Udaipurwala et al. showed ossicular damage in $76(52.05 \%)$ cases. The reason for this deviation may be that in their study both atticoantral and tubotympanic diseases were included, where in our study only atticoantral type was included.

The characteristic bony changes that occur in CSOM (AA) is due to the presence of cholesteotoma and granulation tissue or both. Numbers of theories such as pressure necrosis, infection, hyperaemic decalcification, enzymatic, chemical and immunogical have been postulated explaining the mechanism of bone erosion by cholesteotoma. In our study there were 27 (100\%) 
D. Shrestha et al, Types of pathology and ossicular status in atticoantral.

cases of ossicular damage in ears with granulation tissue whereas in cholesteotomatous cases only $54(88.52 \%)$ had ossicular destruction. In a study done by V. jahnke and W. Falk. ${ }^{12}$ ossicular destruction was found in $77 \%$ cases with cholesteotamous cases. In another study J. Karja. ${ }^{13}$ revealed ossicular chain was damaged in $75 \%$ cases with cholesteotoma. In another study done by A. Palva et.al. ${ }^{14}$ ossicular damage was found in $65 \%$ of cholesteotomous disease.

In this study $\mathrm{M}+\mathrm{S}+$ ossicular defect was the commonest type of defect in 47(50.53\%)cases followed by M+S- 24(25.80\%)cases. M-S+ defect was seen in13 $(13.97 \% \%)$ cases and M-S- defect was seen in $9(9.67 \%)$ cases in a similar study done by Thapa et. al. $\mathrm{M}+\mathrm{S}+$ was the commonest defect $41.67 \%$ followed by $\mathrm{M}+\mathrm{S}-(25 \%), \mathrm{M}-\mathrm{S}+(5.55 \%)$, and M-S-(18\%). In Austin's ${ }^{15}$ series, $\mathrm{M}+\mathrm{S}+$ defect was found in $59.2 \%$ patients followed by $\mathrm{M}+\mathrm{S}$ (23.2\%), M-S+ (7.8\%), and M-S- (8.2\%).

\section{Conclusion}

In this study it is concluded that in Chronic otitis media atticoantral type cholesteotoma is the commonest pathology 61(61\%) followed by granulation tissue alone in 27 (27\%)and both cholesteotoma and granulation12(12\%) cases.

Ossicular damage is more common in CSOM (AA) with granulation tissue i.e. in all $27(100 \%)$ cases, $54(88.52 \%)$ cases in $\operatorname{CSOM}(\mathrm{AA})$ with cholesteotoma and in all $12(100 \%)$ cases of CSOM(AA) with both cholesteotoma and granulation tissue.
$\mathrm{M}+\mathrm{S}+$ ossicular defect is the commonest ossicular defect found in total $47(50.53 \%)$ cases followed by $\mathrm{M}+\mathrm{S}-24(25.80 \%), \mathrm{M}-\mathrm{S}+13(13.97 \%)$ and $\mathrm{M}-$ S-9 $(9.67 \%)$ cases.

\section{References}

1. H.F.Schuknecht Chronic suppurative otitis media and mastoiditis. Pathology of the ear, massaehusettes common fund book 1976; 222.

2. R.P. Mills. Management of chronic suppurative otitis media, Scott-Brown's otolaryngology, 6th edition 1997;3-10

3. W.L.Meyerhoff, C.S. Kim, M.M. Paparella Pathology of chronic otitis media, Ann Otol Rhinol Laryngol, 1978;87:749-60.

4. E. Michael. Glasscock, E. George. Shambaugh. Pathology and clinical course of inflammatory disease of the middle ear. 4th edition.1990;7:190-2.

5. P.M. Shenoi. Management of chronic suppurative otitis media. In: Kerr AG, Booth JB eds. Scott-Brown's otolaryngology, 5th Edn.1987;3:215-27.

6. I.H. Udaipurwala, K. Iqbal, G. Saqualain et al Pathological profile in chronic suppurative otitis mediaThe regional experiences. J Pak Med Assoc. 1994;44:235-7.

7. D.K. Banskota, B.K. Sinha, R. Prasad et al Amatya RCM, Bhattarai H,Guragain. Per-operative findings: Extent of cholesteotoma in middle ear cleft.Indian $J$ otol.1998;4:61-5.

8. O.P.Sachadeva, S.P.Gulati, V.Kakar, et al. Correlation of clinical, Radiological and Surgical manifestations of cholesteotoma,Pakistan Journal of otolaryngology. 1993;9:177-81. 
Journal of College of Medical Sciences-Nepal,2010, Vol-6,No-4

9. N.M. Thapa, H.Bhattarai, R.C.M. Amatya.Types of pathology and ossicular status in atticoantral disease undergoing mastoid exploration at TUTH. J.Inst.Med.,Jul-Sept/Oct-Dec 2001;24:3-4.

10. W.L.Meyerhoff, C.S. Kim, M.M. Paparella Pathology of chronic otitis media. Ann Otol Rhinol Laryngol. 1978; 87:749-60.

11. W.Y. Chao, C.C. Wu Hearing impairment in chronic otitis media with cholesteotoma. J Formos Med Assoc. 1994; 93:866-9.
12. V. Jahke, W. Falk. Clinical, Pathological and therapeutic aspects of cholesteotoma in children. Laryngol Rhinol Otol Stuttg. 1976; 55:556-60.

13. J. Karja, K. Jokinen, A. Seppala. Destruction of ossicles in Chronic otitis Media. J Laryngol Otol. 1976; 90:50918.

14. A. Palva, P. Karma, J. Karja Cholesteotoma in Children. Arch Otolaryngol. 1977; 103:74-7.

15. D.F. Austin Ossicular reconstruction. Arch Otorhinolaryngol. 1971; 94:143-8. 